\title{
Preoperative Fondaparinux for Deep Vein Thrombosis in Patients with Hip Fractures
}

\author{
Adela Hilda Onutu*, Iacob Ioana Maria and Calin Rusan \\ Department of Anesthesiology and Intensive Care, Orthopedic and Traumatology Clinic "Alexandru Radulescu", Emergency \\ County Hospital Cluj-Napoca, Romania
}

*Corresponding author: Adela Hilda Onutu, Department of Anesthesiology, and Intensive Care, Orthopedic and Traumatology Clinic "Alexandru Radulescu”, Emergency County Hospital Cluj-Napoca, Romania

\begin{tabular}{|c|c|}
\hline ARTICLE INFO & ABSTRACT \\
\hline Received: 㟵 July 09, 2020 & Citation: Adela Hilda Onutu, Iacob Ioana Maria and Calin Rusan. Preoperative \\
\hline Published: 幽 July 20, 2020 & $\begin{array}{l}\text { Fondaparinux for Deep Vein Thrombosis in Patients with Hip Fractures. Biomed J Sci \& } \\
\text { Tech Res 29(1)-2020. BJSTR. MS.ID.004734. }\end{array}$ \\
\hline
\end{tabular}

\section{To the Editor}

Deep vein thrombosis (DVT) is a frequent finding in patients presenting with hip fractures [1]. Current recommendation on DVT management with unfractionated heparin (UNH) might be difficult and prone to complications in some circumstances. International guidelines enable the use of fondaparinux in DVT management [2]. Fondaparinux displays some advantages in DVT management: a single subcutaneous injection, no need for laboratory monitoring, a reduced incidence of intolerance reactions, and no risk for HeparinInduced Thrombocytopenia (HIT) [2-4]. This retrospective case series aimed to gather information about its preoperative use in our clinic. We assessed the efficacy of the treatment with fondaparinux, and secondary we recorded the need for perioperative transfusion and other postoperative complications. Data obtained from 138 records of the patients treated with 7.5 mg ( $5 \mathrm{mg}$ in patients under $50 \mathrm{~kg}$ ) fondaparinux (Arixtra ${ }^{\circledR}$, Glaxo Wellcome Production, Notre Dame de Bonneville, France), for DVT, entered the database. The patients with DVT have had their diagnosis established by Doppler ultrasound, and the same test was repeated after five days of treatment, in each patient. We registered demographic data, co-morbidities, pretreatment with low molecular weight heparins (LMWH), dose and duration of treatment with fondaparinux, time to surgery after cessation of fondaparinux, type of anesthesia, the in-hospital mortality, and the hemorrhagic events. The amount of blood transfusion (number of units transfused) until the fourth postoperative day was recorded. The transfusion criteria were hemoglobin $<7 \mathrm{~g} / \mathrm{l}$ or hemodynamic instability in circumstances of blood loss. In patients with coronary heart disease, the targeted hemoglobin level was $10 \mathrm{~g} / \mathrm{l}$. In patients with persistent DVT after fondaparinux administration, the subsequent treatment applied was recorded as well as the complications if these occurred.

Data were expressed as mean, standard deviation (SD), median (range), numbers and percentiles. Out of 138 patients' files, four were dropped out because of lacking information, and a remaining 134 of medical records entered the study analysis. Patients' age was between 24 and 94 years with a median of 75 years, 53 (39.5\%) were male and $81(60.5 \%)$ female. The demographic data and risk factors for DVT are presented in Table 1. One hundred and eight patients (80.5\%) with DVT who received fondaparinux have been gone further with surgery, and 98 patients received spinal anesthesia and 10 general anesthesia. We did not record any evidence of heparin-induced thrombocytopenia, major bleeding, or spinal/ epidural hematoma. In Table 2 we registered data regarding the treatment with fondaparinux and its complications. Fondaparinux was efficient in $89.6 \%$ of cases, to treat venous thrombosis. There is a lack of literature regarding the preoperative use of 7.5 mg fondaparinux for DVT, even if there are confirmations on its efficiency and safety, in various situations [5,6]. Our study showed efficacy and safety with the preoperative use of fondaparinux, even if regional anesthesia was used. The above data have been collected in only one single medical center and there is a need for further studies to validate our findings. 
Table 1: Demographic data and risk factors in studied patients $(n=134)$.

\begin{tabular}{|c|c|}
\hline Characteristics & Values \\
\hline Age (yr), median (range) & $75(24,94)$ \\
\hline Gender composition (number male/female) & $53 / 81$ \\
\hline Obesity [n, (\%] & $8(5.9 \%)$ \\
\hline Diabetes [n, (\%)] & $10(7.4 \%)$ \\
\hline Neoplasm [n, (\%)] & $7(5.2 \%)$ \\
\hline Cardiovascular disease (cardiac insufficiency, stroke) [n (\%)] & $30(22.3)$ \\
\hline DVT history [n, (\%)] & $7(5.2 \%)$ \\
\hline Antiphospholipid syndrome [n, (\%)] & $1(0.74 \%)$ \\
\hline
\end{tabular}

SD - standard deviation; DVT - deep vein thrombosis; $\mathrm{n}$ - number of patients.

Table 2: The fondaparinux treatment characteristics and complications.

\begin{tabular}{|c|c|}
\hline Characteristics & $\begin{array}{c}\text { Values } \\
(n=134)\end{array}$ \\
\hline Time from cessation of fondaparinux to surgery (hours), [median (range)] & $36(36,48)$ \\
\hline Inefficacy of the treatment $[\mathrm{n},(\%)]$ & $14(10.4 \%)$ \\
\hline Transfused patients $[\mathrm{n},(\%)]$ & $63(47 \%)$ \\
\hline Transfused PRB units/patient [median (range)] & $1(1,4)$ \\
\hline Hemorrhagic events [n, (\%)] & $1(0.74 \%)$ \\
\hline Mortality [n, (\%)] & $5(3.73 \%)$ \\
\hline
\end{tabular}

PRB- packed red blood cells, SD - standard deviation, $\mathrm{n}$ - number of patients.

\section{References}

1. Bengoa F, Vicencio G, Schweitzer D, Lira MJ, Zamora T (2018) High prevalence of deep vein thrombosis in eldery hip fracture patients with delayed hospital admission. Eur J Trauma Surg.

2. Kearon C, Kahn SR, Agnelli G, Goldhaber S (2008) American College of Chest Physicians. Antithrombotic therapy for venous thromboembolic disease: American College of Chest Physicians Evidence-Based Clinical Practice Guidelines. In Kearon C, Kahn SR, Agnelli G, Goldhaber S (Eds.), ( $8^{\text {th }}$ Edn.)., Chest 133(Suppl 6): 454S-545S.

3. Garwood CL, Gortney JS, Corbett TL (2011) Is there a role for fondaparinux in perioperative bridging? Am J Health Syst Pharm. 68(1): 36-42.

ISSN: 2574-1241

DOI: $10.26717 /$ BJSTR.2020.29.004734

Adela Hilda Onutu. Biomed J Sci \& Tech Res

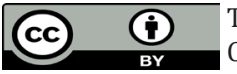

This work is licensed under Creative Commons Attribution 4.0 License

Submission Link: https://biomedres.us/submit-manuscript.php
4. Büller HR, Davidson BL, Decousus H (2004) Fondaparinux or enoxaparin for the initial treatment of symptomatic deep venous thrombosis: a randomized trial. Ann Intern Med 140(11): 867-873.

5. Nagler M, Haslauer M, Wuillemin WA (2012) Fondaparinux - data on efficacy and safety in special situations. Thromb Res 129(4): 407-417.

6. Schindewolf M, Scheuermann J, Kroll H (2012) Application, tolerance, and safety of fondaparinux therapy in a German hospital: a prospective single-centre experience. Thromb Res 129(1): 17-21.

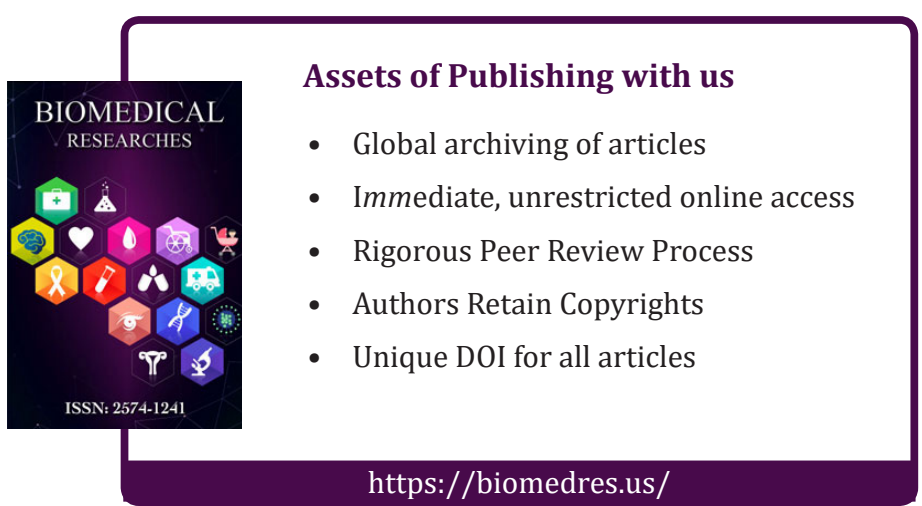

